\title{
Study on the Interactive Learning of Business English Based on Network Information Technology
}

\author{
LU Sun ${ }^{1, a^{*}}$ \\ ${ }^{1}$ Harbin University of Commerce, Harbin, China, 150028 \\ aSUN_LU1980@163.com
}

Keywords: Information technology; business English; interactive learning

\begin{abstract}
Business English interactive learning is an important development direction of business English teaching. This paper analyzes the theoretical basis of the network information technology environment and its interactive learning, and focuses on the application of several interactive learning methods in business English teaching.
\end{abstract}

\section{Introduction}

In order to meet the needs of China's social development and international exchanges, we have promoted the reform of college English teaching and implemented the concept of modern education. In January 2004, the Ministry of Education officially launched the "College English Teaching Requirements (Trial)": "We should make full use of Multimedia, network technology development opportunities, the use of new teaching model to improve the original teacher-based teaching a single classroom teaching model, so that English teaching toward personalized learning, from time and place restrictions on learning. It shows the importance of modern science and technology - network in college English teaching, and further mentions that "both teachers and students should be fully mobilized", "should pay attention to teachers' face-to-face counseling" and "new teaching mode In the technical should reflect the interactive, achievable and easy to operate."This reflects the individual learning through the guidance of teachers, language learning cannot be separated from the mutual cooperation, that is," interactive learning "(collaborative Learning, the main practice is to divide the students into groups to complete a common study Standard. Therefore, based on the implementation of interactive learning English at the University of network information technology environment is the current college English teaching reform process is an important trend.

In the rapid development of information science and technology today, the computer has penetrated into every area of today's society, the application of computer for us brought about the efficiency, flexibility, convenience has become an indisputable fact, especially in recent years, multimedia technology Perfect and more computer applications into a new realm. Throughout the 21 st century, modern education is no longer just "chalk plus mouth" of the traditional model, modern educational technology personal computer (PC) plus multimedia is bound to be introduced into the teaching field. Multimedia classroom full use of today's latest computer network technology, monotonous, boring classroom knowledge image is reflected in the sound, images, movies, animation, it is through the use of computer network technology, making the real exchange based on the discussion of this new Teaching methods become possible, greatly enhance the students' awareness of teaching participation, and further improve the quality of English teaching.

\section{On the information Technology Environment}

The learning environment of the students in the network environment includes the organizational environment, the resource environment and the hardware environment. Organizational environment refers to the division of the collaboration group, the group members of the task allocation, collaboration and so on. When forming teams, and improve the effect of collaborative learning based on student achievement, knowledge structure, cognitive methods, commonly used complementary forms of help. Resources and environment can be provided in the campus network for students, but this is limited to students in the campus of collaborative learning, you can also use 
virtual technology to establish the corresponding site of the Internet, even if students are not at school, at home, or in another city, Can continue to work with groups / groups through the Internet. The hardware environment is CSCW (Computer Supported Cooperative Work) that is computer-supported collaborative work and WWW-based collaborative learning. CSCW is an emerging technology that integrates human cooperative behavioral models with computer support technology and is a field of research on a common task (ie, CW) that is based on a computer technology support environment (ie CS).

\section{About Interactive Learning}

Interactive learning refers to the way students learn to achieve a common learning goal in a group form. Its theoretical basis is the constructivist learning theory. Constructivism is a unique view of learning developed on the basis of cognitiveism. It argues that "learning should not be seen as a passive acceptance of knowledge granted by teachers, but rather learners based on their own knowledge and experience Of the construction activities ". In other words, students are learning in teachers to create situations, with the prior knowledge and experience, take the initiative to explore and actively exchanges, so as to establish a new process of cognitive structure. It advocates that learning is the process of learners' initiative to construct their own knowledge and experience. It is through the interaction of new experience and original knowledge and experience, enriching and transforming the process of knowledge and experience. In the process of constructivism teaching, the learners' learning is not a kind of "isolated" individual competition behavior, which is not the result of the traditional teaching view, but mainly through the cooperation between teachers and students. Therefore, it requires the teaching organizers to design various learning tasks according to the teaching content, so that learners through the group to discuss the exchange, learn from each other, promote each other, share learning materials, give full play to the enthusiasm of the team members, initiative, creativity and mutual assistance, Thereby accomplishing the assigned tasks or resolving a problem. The theory and practice of collaborative learning have been applied abroad for a long time. According to David W. Johnson and Roger T. Johnson's theory of social interdependence,

Learning includes five basic elements: Positive Interdependence, Promotive Interaction, Individual A ccountability, Social Skills, and Group Processing. According to this theory, learners participate in small groups, in order to achieve common learning goals, under certain incentives to maximize individual and team achievements acquisition and cooperation and mutual assistance.

\section{The Implementation of Business English Interactive Learning in Network Information Technology Environment}

The so-called interactive learning based on the network information technology environment refers to the use of computer networks and multimedia and other related technologies, teachers to explain the learning content to the students, between teachers and students, students and students can conduct a discussion on a learning content online, Exchange information, in order to achieve a more profound understanding of teaching content and master. In the collaborative learning using the network, both human-computer interaction, but also between people to interact. Collaborative learning in the network is a place and time constraints of learning, in the learning process, ready access to online help and information resources. This kind of learning is usually done in the form of group learning, which is the central part of network collaboration learning. There are many forms of group learning, such as competition, discussion, coordination, problem solving, partner, design and role play. Here, we mainly discuss several in the implementation of business English teaching:

\section{Competition Cooperation Type}

Competitive type refers to two or more learners for the same learning content, through the network for competitive learning. In this form, learners pay more attention to competing with other learners 
than to cooperate with them. Teachers in the computer learning system to set up learning objectives and learning content, and to provide learners to solve the problem related information. Learners can first select a competitor from the list of online learners online and negotiate a competitive agreement, and then begin to solve the problem independently and see who will complete the task. Competition in the form of collaborative learning, is conducive to stimulate students' learning confidence and morale, and enhance learners learning initiative and initiative. If it is a competition among individual learners, learners can understand and learn from the opponent's learning process and promote their own learning activities and improve their learning skills. If you learn from the competition between groups, you can encourage all team members to redouble their efforts to get better team results.

To Discuss Collaborative Type. Discussion group usually 3-5 people, an excessive number of discussions will be difficult to control, but also make learners lose interest; too few in number may be too onerous task, insufficient amount of information. Through the network, collaboration, team members can choose, free combination, and to discuss response to a question raised by teachers, consultations, finally reached consensus on the issue. In the process of solving the problem, the collaborators can use the virtual library or network to access a large amount of information to provide the basis and material for solving the problem. The final outcome of the discussion can be reports, courseware presentations or essays. In order to make their team a better result, the members of the group work together, make plans, so that each student's personal self-esteem, self-confidence and group sense of honor are naturally transformed into learning motivation and passion. At the same time, it plays an important role in fostering and improving the ability of learners to deal with and solve problems.

Partner Cooperation Type. The learning group is composed of two people, the learners to form a partnership for the completion of a learning task, partners to discuss issues of common concern and consultation, and from the other side to try to get the problem of thinking and inspiration, but also for learning Check each other and help each other. This type of collaborative learning is characterized by: learners themselves to find partners, learners usually first choose their own learning content, and then through the network to find the same content in the other learners, choose one of the learners, Agree to be a learning partner. Of course, the learning partner can be a learner or a computer. Partner form can make collaborative learning in a more harmonious atmosphere, can make learners feel in the study has been a partner can support each other and help, once the problem occurs, you can always contact with each other, is conducive to collaborative learning Done successfully.

The role of Interchangeable Type. The group consists of two people. They act as learners and mentor roles, learners are responsible for answering questions, and instructors judge and analyze learners' answers. When learners encounter difficulties in answering questions, they help learners to solve Difficulties. In helping to learn, the roles they play are interchangeable. Through role play, so that each learner's understanding of the problem will enter a new level. The success of role play will increase the learner's sense of accomplishment and sense of responsibility, but also stimulate the learners to master the knowledge of interest. The above four groups of learning forms for the basic form of network collaborative learning, in the actual collaborative learning can be selected according to the situation and integrated use in order to achieve the best learning results.

\section{Conclusions}

In the business English teaching in the implementation of interactive learning, learners feel that students are no longer competing opponents, but to promote learning helper. The interactive learning can promote the learners to take the initiative to participate in the learning process, effectively stimulate the learners' interest in learning, and fully mobilize the learners as the initiative of the cognitive body and enthusiasm, so that learners learning activities more lively and colorful. 


\section{Acknowledgements}

This paper is supported by Philosophy and Social Scientific Research Project Foundation of Heilongjiang Province (No.14C009).

\section{References}

[1] Wei Chuanli, Practice and theoretical basis of public management research in China, China Electronic Commerce .2012. (10)

[2] Wei Chuanli, On the Problems in the Study of Public Administration in China, China's Foreign Trade $2012(8)$

[3] Sun Lu, Study on Self-learning of Business English Students by Network, MEICI2015, 2015.10

[4] Sun Lu, The Practice of Business English Cooperative Learning in the Network Environment, ICEMC2016,2016.05

[5] Sun Lu, raining of Foreign Trade-Oriented Business English Major, ICEMC2016,2016.05

[6] Sun Lu, On Using Podcasting to Teach in Mobile Foreign Language Learning, EMCM2016,2016.12

[7] Sun Lu, Discussion on the Reform of Foreign Language Teaching in College, EMCM2016,2016.12

[8] Sun Lu, Discussion on the Training Mode of Business English Major, EMCS2017.05

[9] Sun Lu, Study on Business English Teaching, EMCS2017.05

[10] Wei Chuanli, SME technical efficiency and scale revenue calculation methods and selection of indicators, Computer modeling and new technologies, 2014.12 